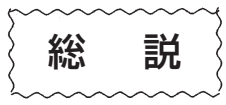

\title{
クドア症
}

\author{
横山 博*
}

(2016年11月 2 日受付)

\section{Kudoosis of Marine Fish in Japan}

\author{
Hiroshi Yokoyama* \\ The University of Tokyo, Bunkyo, Yayoi 1-1-1, Tokyo 113-8657, Japan
}

(Received September 14, 2016)

\begin{abstract}
Kudoosis of marine fish is caused by the multivalvulid myxosporean parasites belonging to the genus Kudoa (Myxozoa). Muscular kudoosis generally lowers the commercial value of host fish, while brain and pericardial kudoosis may directly affect the health conditions of infected fish. Recent topics on Kudoa septempunctata causing the food poisoning of humans which consume raw olive flounder have presented a new threat to public health. The bi-phasic life cycles of bivalvulid myxosporeans alternating fish and annelid hosts have been revealed, but the lack of knowledge on the life cycles of multivalvulid myxosporeans is hindering the progress of Kudoa research. In this paper, several major kudoosis including $K$. amamiensis, $K$. iwatai, $K$. thyrsites, $K$. septempunctata, $K$. yasunagai and $K$. shiomitsui in Japanese fishes are reviewed from the viewpoint of the disease history, pathobiology, diagnosis, and the control measures.
\end{abstract}

クドア症は, ミクソゾア門多殼目に属するクドア属粘 液胞子虫類による感染症である（江草，1986）。クドア 属には80種類以上が記載されており，そのほとんどすべ てが海産魚に寄生する（Table 1)。なかでも商品価値を 低下させる筋肉クドアが有名であるが, 脳や心臟に寄生 して宿主魚に病害を及ぼす種類もある。また，最近では ヒラメのナナホシクドアのように，人間が生食すると食 中毒を起こす事例も報告されている（佐藤，2011）。

粘液胞子虫類の生物学的研究は, 1980年代に著しい進 展があった。サケ科魚類の旋回病原因種Myxobolus cerebralis は魚体外に出た後, 環形動物の 1 種（イトミ ミズ）に取り込まれ，放線胞子虫に変態して初めて魚に 感染するという二相性生活環の発見である（Wolf and Markiw, 1984)。しかしながら多殼目では現在まで 1 種類 も生活環が特定されていない。これがクドア研究の発展 を妨げている最大の要因である。本総説では，国内で問 題となっている主要なクドア類について紹介する。

多殼目粘液胞子虫は, 以前は殼片と極囊の数により 6
つの属に分かれていたが, 最近の分子系統学的研究から 4 個以上の殼片および極囊をもつものはすべてKudoa 属 に統合された。また，種レベルの分類も，以前は胞子の 形態的特徴のみでなされていたが, 現在では $18 S$ と $28 \mathrm{~S}$ rDNA の塩基配列を併用することが推奨されている。そ こで，すでにGenBankに登録されている遺伝子配列に ついては，できる限り表中に登録番号を記した。

また, 江草（1986）の総説で提案されたように, 胞子 の測定值とくに幅と厚さの測り方は論文によって統一さ れていないことから，上面観で最大径の部分を「径」と して測るのが便宜的と考え，それに従った。なお，近年， 日本産養殖魚介類の寄生虫の標準和名目録が作成された ので（横山・長澤，2014），本総説ではなるべく和名を 用いて記述することにした。

今後の課題として, 交互宿主となる多毛類などの環形 動物を特定して生活環を解明すること，また人間に有害 な種類の毒性メカニズムを明らかにすることが挙げられ る。

\footnotetext{
東京大学大学院農学生命科学研究科

* Corresponding author

E-mail: ayokoh@mail.ecc.u-tokyo.ac.jp
} 


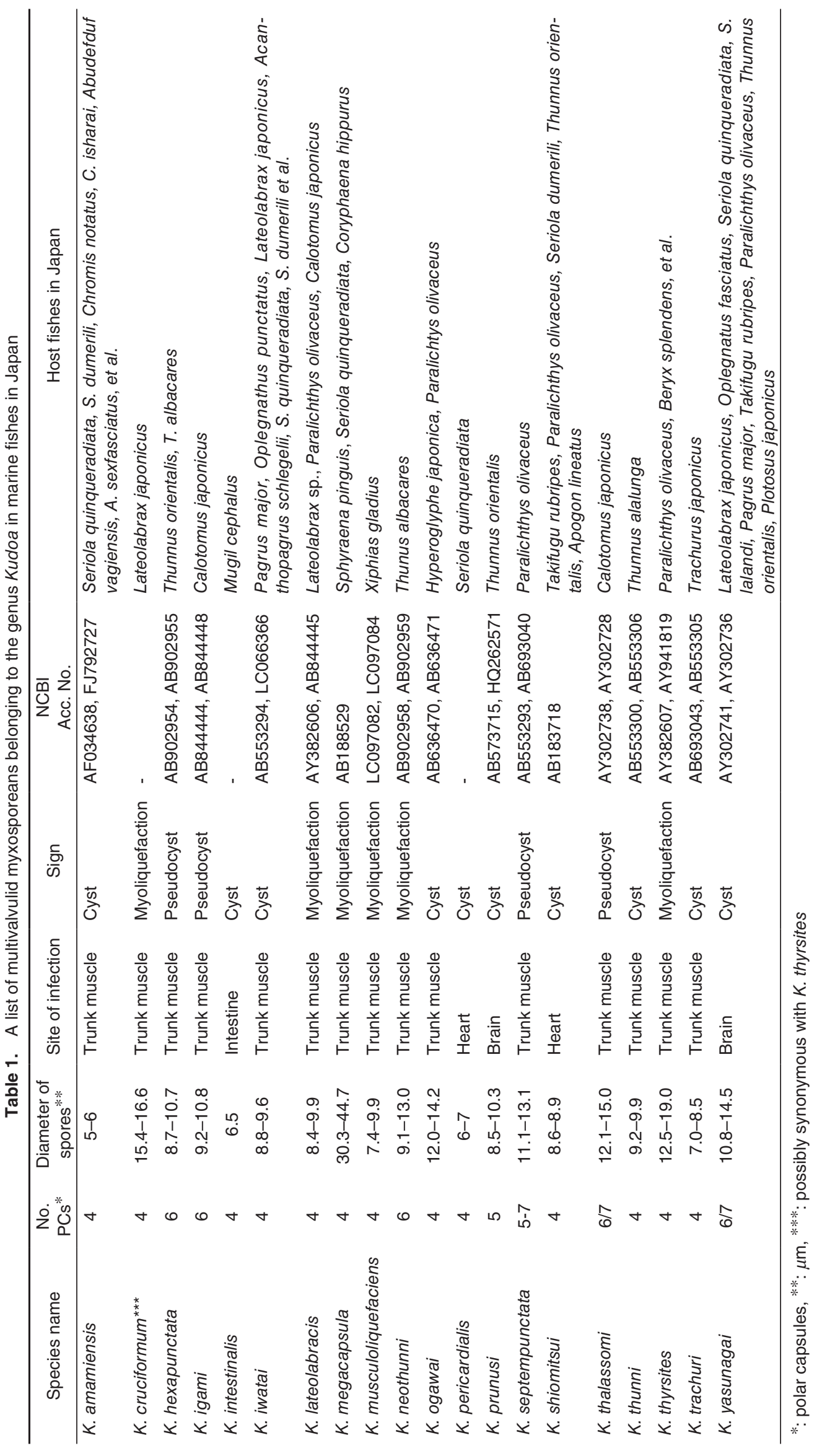




\section{奄美クドア症}

\section{歴史}

1970年，奄美大島のブリ養殖場においてアマミクドア （Kudoa amamiensis）が初めて発見されて以来，70年代 半ばに沖縄県本部町で開催された沖縄国際海洋博覧会の 展示の一つであった「海洋牧場」のブリにも寄生がみら れた（江草・中島，1978）。ブリにとって奄美・沖縄水 域は天然の生息域ではないため, 在来宿主の調査が行わ れた結果，スズメダイ類にアマミクドアの軽度寄生が確 認された。この事例以降，本症は同海域での風土病と認 識され，ブリ養殖は打ち切りとなった。

ところが1990年代に入って沖縄海域でカンパチ養殖の 話が持ち上がり，改めて本症の分布域や魚種による感受 性の違いに注目が集まった。そこで，ブリとカンパチ人 工種苗を沖縄県内に導入して大規模な飼育試験がなされ た結果，本部ではブリの寄生率が100\%，カンパチでは 最大 $90 \%$ であったものの，カンパチの平均寄生強度（シ スト数）はブリより低かった。一方，本部から至近距離 の伊江島をはじめ, 塩屋, 与那城, 与那原, 石坦島では $0 \%$, 運天原や今帰仁, 知念, 系満, 安室島での寄生率 はせいぜい数\%であった。以上より，アマミクドアの地 理的分布は予想以上に限定されており，カンパチはブリ に比べて感受性が低いことが示された（杉山ら，1999）。

さらに後年, オーストラリア東海岸のグレートバリア リーフで採集された野生のハタンポ属魚類，テンジクス ズメダイ，オヤビッチャ属魚類，およびギンガメアジに もアマミクドアの寄生がみられた。この結果, アマミク ドアは日本以外にも分布していることが初めて示され， 宿主特異性の低さとサンゴ礁魚が天然の保有宿主になっ ていることが改めて示唆された。

\section{病原体}

病原体はアマミクドアである。魚体内では，体側筋肉 の筋繊維細胞内に定着後, 発育途中で結合組織に取り囲 まれて大きさ 1〜2 $\mathrm{mm}$ の白色粒状シストとして認めら れる (Fig. 1)。

\section{診断法}

魚を三枚卸しにしてシストを肉眼観察したのち，顕微 鏡検査により胞子の形態を調べる。塗抹標本を作製して， メイグリュンワルド・ギムザ染色またはディフクイック 染色を行う。胞子の径は 5 6 $\mu \mathrm{m}$ である。その他, 間接 蛍光抗体法と PCR 法（Yokoyama et al., 2000），また LAMP 法も開発されている。

\section{防除・予防}

奄美・沖縄海域でブリ類の養殖や中間育成をしないこ

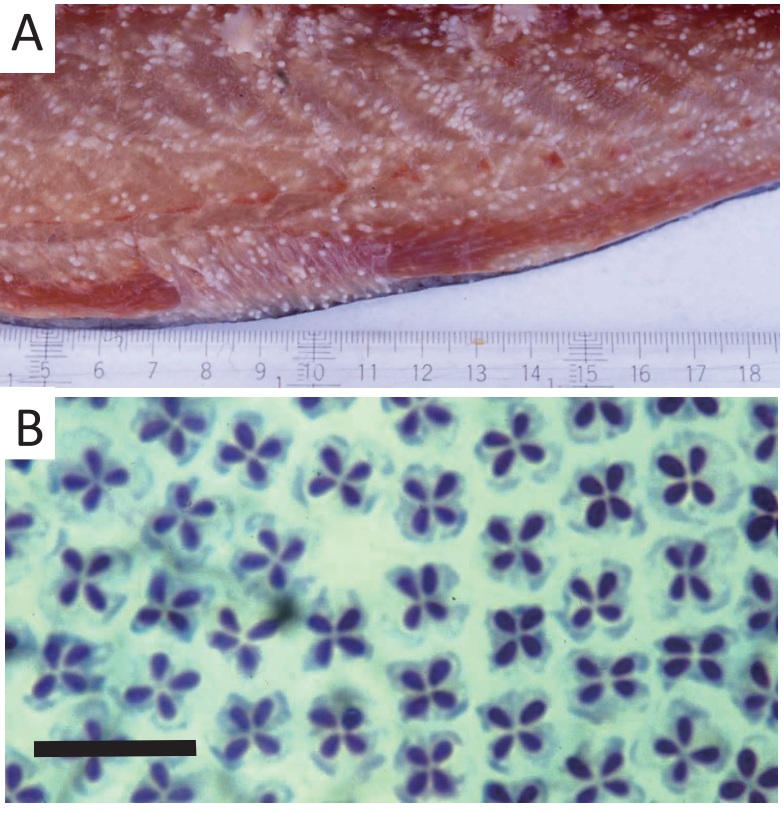

Fig. 1. Kudoosis amami of yellowtail Seriola quinqueradiata (A) and Giemsa-stained spores of Kudoa amamiensis (B). Scale bar is $10 \mu \mathrm{m}$.

とが望ましいが，最近，紫外線照射によりアマミクドア の感染を防除できることが証明された（Shirakashi et al., 2014)。

\section{筋肉クドア症（イワタクドア）}

\section{歴史}

1982年，宮崎県の養殖イシガキダイと鹿児島県の養殖 マダイの体側筋肉内に径 $1 \mathrm{~mm}$ 程度の白色粒状シストが 見つかり，イワタクドア（Kudoa iwatai）と命名された。 その後, 本種は日本のクロダイ, スズキ, サワラ, ブリ およびカンパチ，地中海ではヨーロッパヘダイ，ヨー ロッパスズキ，ボラおよび天然のフエフキダイ科やスズ メダイ科魚類などでも見つかっている（Matsukane et al., 2011)。

\section{病原体・診断法}

病原体はイワタクドアである。診断は，魚体を三枚卸 しにしてシストを肉眼観察したのち，胞子の形態を調べ る。胞子の径は 8.8～9.6 $\mu \mathrm{m}$ である（Fig. 2）。

\section{筋肉クドア症（ジェリーミートまたは死後筋肉融解）}

\section{背景・病原体}

魚の収穫後，筋肉がどろどろに溶けるため商品価值を 失う疾病である。病原体は各種海産魚のホシガタクドア (Kudoa thyrsites), メカジキの K. musculoliquefaciens, タイリクスズキとヒラメのタイリクスズキクドア（K. lateolabracis), キハダのキハダクドア (K.neothunni) 


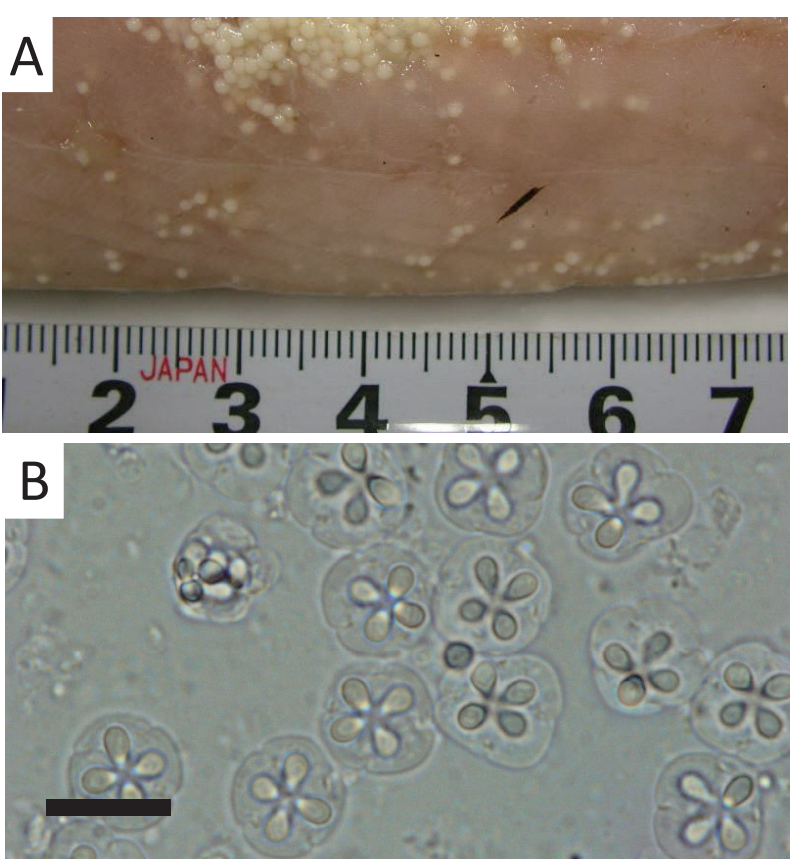

Fig. 2. Muscular kudoosis of Japanese Spanish mackerel Scomberomorus niphonius (A) and fresh spores of $K$. iwatai (B). Scale bar is $10 \mu \mathrm{m}$. Images are cited from Yokoyama (2009).

およびアカカマスのダイキョクノウクドア（K. megacapsula）である。魚体内では体側筋の筋繊維細胞 内で偽シストを形成し, 主に魚の死後, 寄生虫由来の蛋 白分解酵素を分泌して周囲の宿主組織を融解するとされ ている。

\section{診断法}

ホシガタクドアは極囊 4 個のうち 1 個がやや大きい点 が特徴である (Fig. 3)。胞子のサイズは, 地理的分布 （国）や宿主の種類などにより多少相違しているが，胞子 径は 12.5〜19.0 $\mu \mathrm{m}$ である。しかし計測值にはかなりの 変異があるため，現在では塩基配列を比較することが推 奨されている。

K. musculoliquefaciens は極囊 4 個であり胞子径は 7.4 9.9 $\mu \mathrm{m}$, タイリクスズキクドアは極囊 4 個のうち 1 個がやや大きく胞子径は 8.4 9.9 $\mu \mathrm{m}$ ，キハダクドアは 極囊 6 個であり胞子径は 9.1〜 $13.0 \mu \mathrm{m}$ である。ダイキョ クノウクドアは殼片 4 個が翼状に伸長して, 極囊 4 個の うち 1 個が異常に大きく，他の 3 個は退化している点に 特徵があり，胞子の最大径は 30.3〜 44.7 $\mu \mathrm{m}$, 大極囊の 長さは 11.7〜 $14.2 \mu \mathrm{m}$ である。

なお，ホシガタクドアとタイリクスズキクドアをナナ ホシクドアと識別するための PCR 法が開発されている (Grabner et al., 2012)。

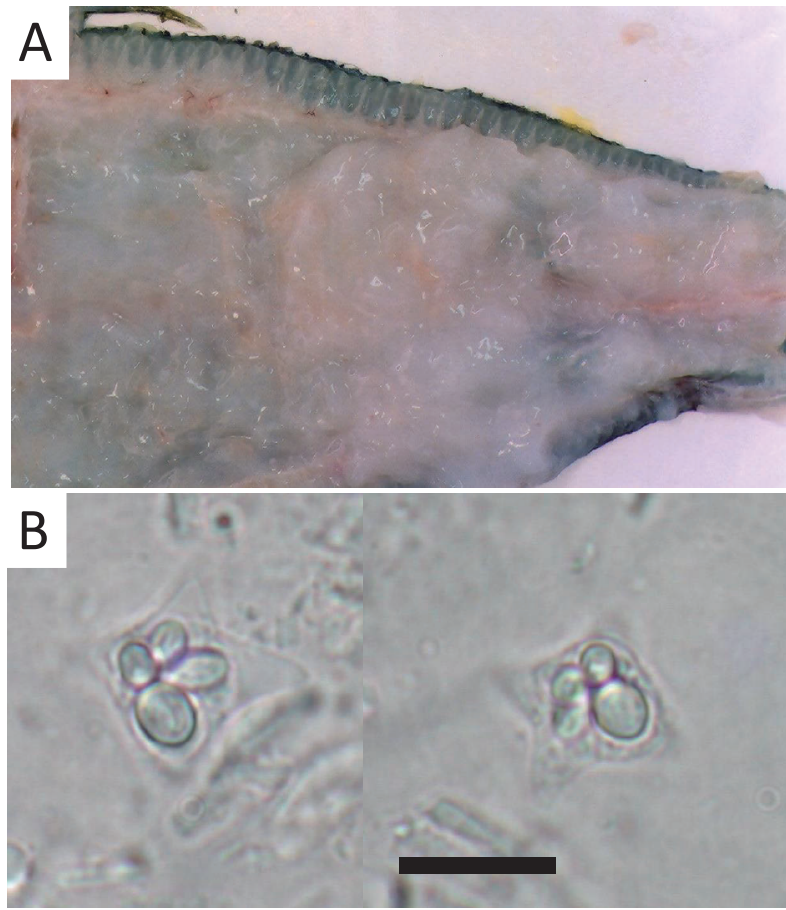

Fig. 3. Post-harvest myoliquefaction of olive flounder Paralichthys olivaceus (A) and fresh spores of $K$. thyrsites (B). Scale bar is $10 \mu \mathrm{m}$. Images are cited from Yokoyama et al. (2004).

\section{クドア食中毒}

\section{歴史}

2011年, ヒラメの筋肉に寄生するナナホシクドア （Kudoa septempunctata）が人間の食中毒の原因になる ことが発表された（Kawai et al., 2012）。これは世界的に も歴史的にも初めての事例であるが，いわゆる風評被害 により養殖ヒラメの生産量が激減したことから水産的に も大きな被害を与えた。まもなく，厚労省から $\left\lceil-15^{\circ} \mathrm{C} \sim-20^{\circ} \mathrm{C} \cdot 4\right.$ 時間以上の冷凍または $75^{\circ} \mathrm{C} \cdot 5$ 分間 以上の加熱で無毒化できる」という対策が提言されたも のの，刺身商材としてのヒラメには実用的でなかった。 その後, 水産庁から, 養殖場への種苗導入時に PCR 検 査，出荷時に顕微鏡検査して感染群を除去する対策が提 案された。また，韓国からの輸入魚に対しては，この食 中毒が胞子の摂取量に依存することを利用して，ヒラメ 筋肉 $1 \mathrm{~g}$ あたりの胞子数が $10^{6}$ 個以上であった場合, 食品 衛生法第 6 条に違反するとした。この厳しい法規制によ り一時的に食中毒事例が減少したが, 近年また増加して いる。

\section{病原体}

病原体はナナホシクドアである。感染 3 週目頃から筋 肉中にPCR で検出されるようになり，筋繊維内で偽シ ストを形成して胞子を産生する。肉眼的にシストもジェ 
リーミートも呈さないのが特徴である（Fig. 4）。

\section{診断法}

ヒラメの種苗期に通常の PCR 法とリアルタイム PCR 法が, 成魚期には胞子を検出する顕微鏡検査法がある。 胞子は極囊 6 ～ 7 個を有し, 径は 11.1〜13.1 $\mu \mathrm{m}$ である。 法規制に付随して筋肉中の胞子密度を計測する方法，ま たイムノクロマトグラフィー法や LAMP 法などを応用し た簡便なキットも市販されている。また，ヒラメは活魚 で流通することから, 注射器を用いて尾柄部から微量の 筋肉組織を採取する生検法もある。しかし，いずれも一 長一短であり, 種特異性, 検出感度, コストおよび作業 性を一律に比較検討する必要がある。

\section{防除・予防}

国産養殖ヒラメについては，種苗の導入時期と成魚の 出荷時期に二重検査して感染魚群を除去する対策が一定 の効果を上げてきた。今後は，種苗生産場で飼育用水を 砂ろ過と紫外線で処理することにより，完全に未感染の 種苗を生産する必要がある（Nishioka et al., 2016）。一 方, 韓国からの輸入ヒラメについては課題が多い。輸入 時に検疫所で検査することが義務づけられているものの, 感染魚の輸入は後を絶たない。
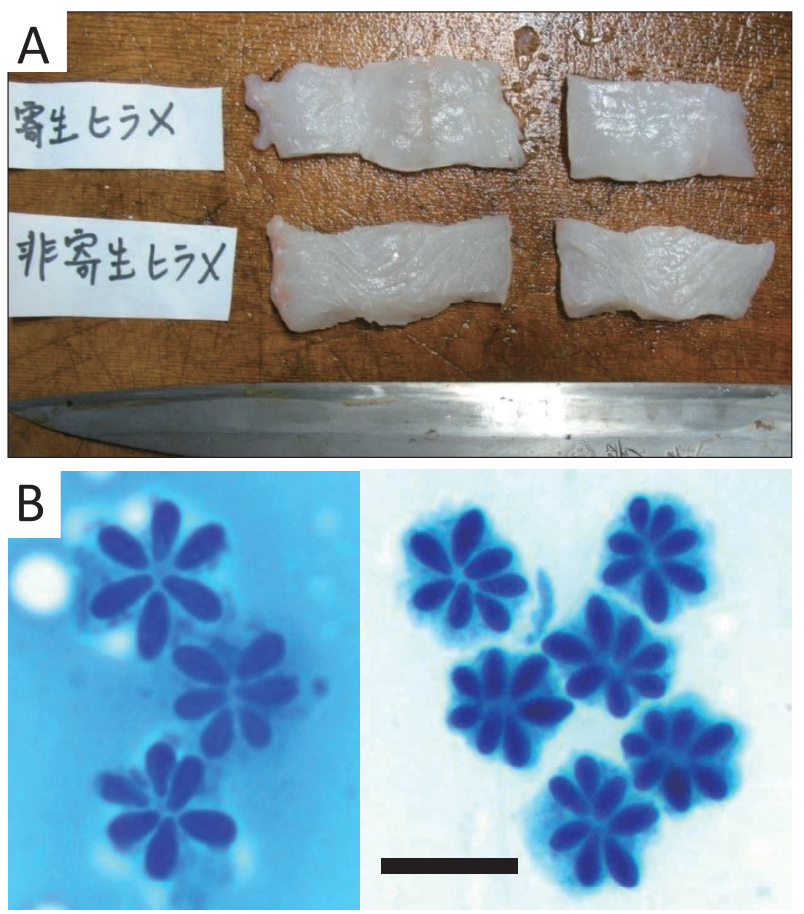

Fig. 4. Sashimi of olive flounder infected with $K$. septempunctata (upper ones in A) and non-infected flounder (lower ones in A). Metylene-blue stained spores of $K$. septempunctata (B). Scale bar is $10 \mu \mathrm{m}$. Images are cited from a web-page of D-PAF (http:// fishparasite.fs.a.u-tokyo.ac.jp).

\section{脳クドア症}

\section{歴史}

1980年頃より，長崎県の養殖スズキとイシダイが異常 遊泳を伴って死亡する事例がみられ，脳粘液胞子虫の寄 生がみられた。いずれの魚種も，もとは韓国から種苗と して導入されたものであったが, その後, 九州地方など で養殖されているブリ，マダイ，トラフグ，ヒラメ，ク ロマグロ，ヒラマサおよび天然のゴンズイでも同じクド アが確認された。極囊の数が主に 7 個であったことから, 新属新種の Septemcapsula yasunagai と命名されたもの の, のちにKudoa yasunagai（ノウクドア）と改名され た。

\section{病原体・診断法}

病原体はノウクドアである。感染ルートや移動経路は 不明であるが，脳でのシスト形成後，徐々に治っていく ことが示唆されている。環境水中では, DNAを捕捉して 定量 PCRにより遺伝子量を測定する試みがなされてい る（Ishimaru et al., 2014）。診断法として, 魚の脳表面の シストを調べ，顕微鏡観察する。胞子は極囊 6 ～ 7 個を 有し，径は 10.8～14.5 $\mu \mathrm{m}$ である（Fig. 5）。

\section{防除・予防}

陸上水槽で用水を紫外線処理することにより，感染防
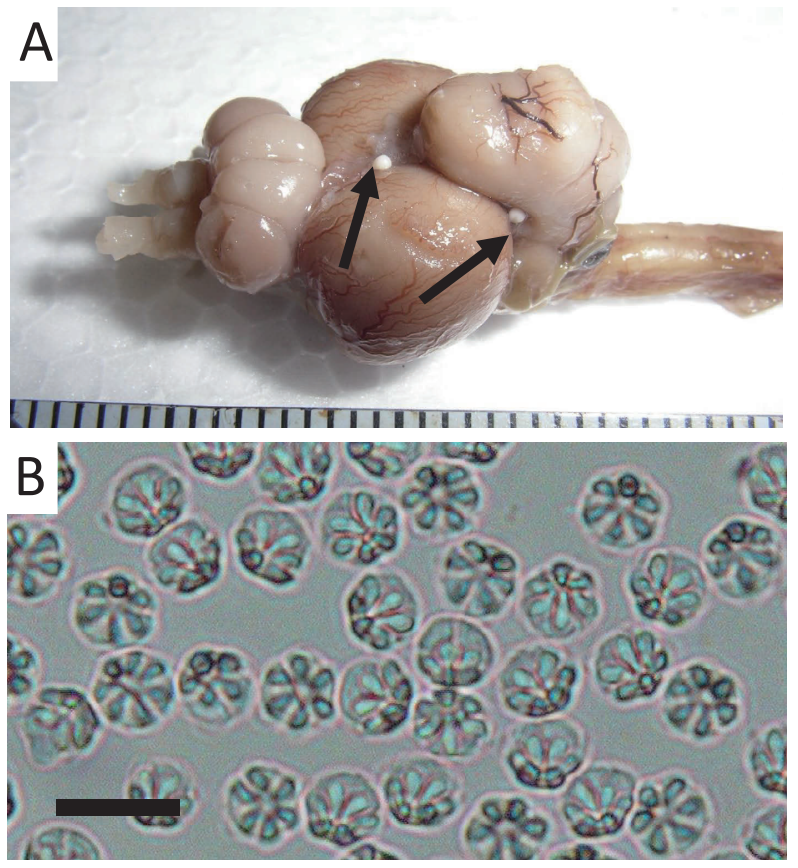

Fig. 5. Brain of yellowtail S. quinqueradiata with $K$. yasunagai cysts (arrows in A) and fresh spores of $K$. yasunagai (B). Scale bar is $10 \mu \mathrm{m}$. Images are cited from a web-page of D-PAF (http://fishparasite.fs.a.u-tokyo. ac.jp). 
除できる（Shirakashi et al., 2014）。

\section{心臓クドア症}

\section{歴史・病原体・診断法}

1970年代に本州，四国，九州地方の養殖ブリの心臟およ び囲心腔内にブリシンゾウクドア (Kudoa pericardialis), 1982年に鹿児島県の養殖トラフグの心臟および囲心腔内 にシンゾウクドア (Kudoa shiomitsui) が見つかった (江草・塩満, 1983)。

前者はブリからしか知られていないが，後者は宿主範 囲が広く，ヒラメ，カンパチ，クロマグロ抢よび天然の テンジクダイからも見つかっている。なお，宿主への病 害性は確認されていない。診断法としては, 心臟表面の シストを検査し顕微鏡で胞子の形態を観察する。胞子は 極囊 4 個を有し，ブリシンゾウクドアの径は $6 \sim 7 \mu \mathrm{m}$, シンゾウクドアの径は 8.6 8.9 $\mu \mathrm{m}$ である。

\section{文献}

江草周三（1986）: 多殼類粘液胞子虫とくにクドア類について. 魚病研究, 21, 261-274.

江草周三・中島健次 (1978)：ブリのアマミクドア症. 魚病研 究, 13,1-7.

江草周三・塩満捷夫（1983）：マダイとイシガキダイの体側筋 寄生クドアおよびトラフグの囲心䏶と心臓寄生クドアにつ いて. 魚病研究, 18, 163-171.

Grabner, D., H. Yokoyama, S. Shirakashi and R. Kinami (2012): Diagnostic PCR assays to detect and differentiate Kudoa septempunctata, K. thyrsites and K. lateolabracis (Myxozoa: Multivalvulida) in muscle tissue of olive flounder (Paralichthys olivaceus). Aquaculture, 338, 36-40.

Ishimaru, K., T. Matsuura, K. Tsunemoto and S. Shirakashi (2014): Seasonal monitoring of Kudoa yasunagai from sea water and aquaculture water using quantitative PCR. Dis. Aquat. Organ., 108, 45-52.

Kawai, T., T. Sekizuka, Y. Yahata, M. Kuroda, Y. Kumeda, Y. Iijima, Y. Kamata, Y. Sugita-Konishi and T. Ohnishi (2012): Identification of Kudoa septempunctata as the causative agent of novel food poisoning outbreaks in Japan by consumption of Paralichthys olivaceus in raw fish. Clin. Infec. Dis., 54, 1046-1052.

Matsukane, Y., H. Sato, S. Tanaka, Y. Kamata and Y. SugitaKonishi (2011): Kudoa iwatai and two novel Kudoa spp., K. trachuri n. sp. and K. thunni n. sp. (Myxosporea: Multivalvulida), from daily consumed marine fish in western Japan. Parasitol. Res., 108, 913-926.

Nishioka, T., J. Satoh, T. Mekata, K. Mori, K. Ohta, T. Morioka, M. B. Lu, H. Yokoyama and T. Yoshinaga (2016): Efficacy of sand filtration and ultraviolet irradiation as seawater treatment to prevent Kudoa septempunctata (Myxozoa: Multivalvulida) infection in olive flounder Paralichthys olivaceus. Fish Pathol., 51, 23-27.

佐藤 宏（2011）：食中毒の新たな寄生虫性病原体として注目さ れる粘液胞子虫の生物学. 山口獣医学雑誌, 38, 1-26.

Shirakashi, S., T. Nishimura, N. Kameshima, H. Yamashita, H. Ishitani, K. Ishimaru and H. Yokoyama (2014): Effectiveness of ultraviolet irradiation of seawater for the prevention of Kudoa yasunagai and Kudoa amamiensis (Myxozoa: Multivalvulida) infections in Seriola fish. Fish Pathol., 49, $141-144$

杉山昭博・横山 博・小川和夫（1999）沖縄県内における奄美 クドア症の疫学的調査. 魚病研究, 34, 39-43.

Wolf, K. and M. E. Markiw (1984): Biology contravenes taxonomy in the Myxozoa: new discoveries show alternation of invertebrate and vertebrate hosts. Science, 225, 14491452 .

横山 博（2009）：養殖現場で多くの被害を引き起こす粘液胞 子虫病の予防と対策. 月刊養殖, 583, 31-34.

横山 博・長澤和也（2014）：養殖魚介類の寄生虫の標準和名目 録. 生物圈科学, 53, 73-97.

Yokoyama, H., D. Inoue, A. Sugiyama and H. Wakabayashi (2000): Polymerase chain reaction and indirect fluorescent antibody technique for the detection of Kudoa amamiensis (Multivalvulida: Myxozoa) in yellowtail Seriola quinqueradiata. Fish Pathol., 35, 157-162.

Yokoyama, H., C. M. Whipps, M. L. Kent, K. Mizuno and H. Kawakami (2004) : Kudoa thyrsites from Japanese flounder and Kudoa lateolabracis n. sp. from Chinese sea bass: causative myxozoans of post-mortem myoliquefaction. Fish Pathol., 39, 79-85. 